\title{
Nutritional response of growing rats to faba beans (Vicia faba L., minor) and faba bean fractions
}

\author{
BY LUIS A. RUBIO, GEORGE GRANT, SUSAN BARDOCZ, PETER DEWEY \\ AND ARPAD PUSZTAI \\ The Rowett Research Institute, Greenburn Road, Bucksburn, Aberdeen AB2 $9 S B$
}

(Received 18 July 1990 - Accepted 25 February 1991)

\begin{abstract}
The effects of raw faba bean (Vicia faba L., minor) meal (VFM) and its fractions on the growth and nitrogen utilization of rats have been determined in two experiments. Two commercial varieties of VFM were tested, local VFM (409-439 g/kg diet) and Troy VFM $(439 \mathrm{~g} / \mathrm{kg}$ diet). The bean fractions tested were $V$. faba lectin-depleted protein (VFDP), $V$. faba lectin (VFL) and $V . f a b a$ cotyledon residue (VFCR). All diets were supplemented with amino acids to target requirements. Body-weight, body $\mathrm{N}$ and lipid contents of rats fed on VFM were reduced significantly in comparison with control rats fed on lactalbumin. This was due, in part, to the lower digestibility of the protein, lipid and dry matter (DM) of VFM diets. As a result, net protein utilization (NPU) and biological value (BV) of faba bean proteins were less than expected. Urine and urea-N outputs of the VFM-fed rats were also elevated in both experiments. Increasing the energy content of local VFM diets led to significantly higher dry bodyweight, body $\mathrm{N}$ and lipid contents, with the result that the NPU and $\mathrm{BV}$ values of the protein also increased. However, the NPU values for VFM-fed rats were still significantly lower than those for the controls in both experiments. In contrast, true $\mathbf{N}$, lipid and DM digestibilities in rats given local VFM were not significantly affected by the difference in the energy content of the diets. The replacement of two-thirds of the lactalbumin in the diet with VFDP $(65 \mathrm{~g} / \mathrm{kg})$ reduced dry body-weight, $N$ and lipid contents, NPU and BV compared with the control rats, even though N, lipid and DM digestibilities were not significantly different. The nutritional performance of rats fed on lactalbumin-based diets containing $7 \mathrm{~g} \mathrm{VFL} / \mathrm{kg}$ was similar to that of the controls. Similarly, the inclusion of the cotyledon residue (237 $\mathrm{g}$ VFCR/kg diet) had no appreciable effect on any of the variables studied. As VFL and VFCR had no antinutritional effects in these rats, it appears that the low nutritional value of VFM for rats (NPU 066) results not only from the low digestibility of the bean proteins, but also from disturbances in $\mathbf{N}$ metabolism.
\end{abstract}

Vicia faba: Nutritional response: Rats

There is considerable interest in faba bean (Vicia faba L., minor) as a source of plant protein. With a production of nearly four million tons, it is one of the major legume crops cultivated in all regions of the world, including Western Europe. Most of this is used for human consumption, mainly as cooked food. Indeed, faba beans are a good source of protein of adequate nutritional quality, particularly in a mixed diet. In contrast, less faba bean is used as animal feed, mainly because of the presence of a number of antinutrients in the seed meal. As heat treatment is costly, most of the meal is not processed. However, with rations containing high levels of untreated meal, slow growth rates and low food intakes have been reported in rats (Marquardt et al. 1974; Moseley \& Griffiths, 1979; Martinez \& Larralde, 1984) and chickens (Marquardt \& Campbell, 1975; Guillaume, 1977; Rubio \& Brenes, 1988). This has been attributed to toxic constituents, the low sulphur amino acid content of faba-bean protein (Marquardt \& Campbell, 1974; Bond, 1980; Boulter, 1982) and the low digestibility of the protein (Huyghebaert et al. 1979) and 
carbohydrate (Mercier, 1979) components. In contrast, for the histological and physiological disorders recently reported for chickens fed on diets containing different levels of raw or autoclaved faba beans or faba-bean fractions (Rubio et al. 1989, 1990), the dietary lectin has been suggested as the main factor responsible for the deleterious effects.

The aims of the present study were to determine the nutritional value for rats of the raw meal (VFM) of two commercially available faba bean varieties and to relate this to the nutritional and physiological effects, on young growing animals, of purified fractions obtained from the seeds, such as the pure faba-bean lectin (VFL), the lectin-free bean proteins (VFDP) and the protein-depleted insoluble cotyledon residue (VFCR).

MATERIALS AND METHODS

Fractionation of the VFM

VFCR (158 g) was obtained after extraction with stirring of dry faba-bean cotyledon meal (VFC, $260 \mathrm{~g}$ ) from the Troy cultivar in PBS $(0.015 \mathrm{M}$-sodium phosphate- $0.15 \mathrm{M}$-sodium chloride, $\mathrm{pH} 7.0$ ) buffer (2 litres) for $24 \mathrm{~h}$ in the cold. The sediment obtained after centrifugation $(20000 \mathrm{~g}, 30 \mathrm{~min})$ was recovered by freeze-drying (VFCR).

The supernatant fraction obtained after centrifugation was treated with ammonium sulphate $(760 \mathrm{~g} / \mathrm{l})$. The precipitate was recovered by centrifugation and dialysed against PBS buffer, and the dissolved proteins were passed through a Sephadex G-100 column. Proteins of the fraction passing through, VFDP, were free of lectin as determined by SDS gel electrophoresis (Fig. 1). This fraction was extensively dialysed against distilled water and freeze-dried. The lectin adsorbed to the column was eluted with $0.2 \mathrm{M}$-glucose in PBS buffer, extensively dialysed against distilled water and recovered by freeze-drying. It was shown to be of high purity (Fig. 1). From the recovery of the lectin by this procedure and by rocket immunoelectrophoresis (results not shown), $V$. faba seeds were determined to contain at least $5 \mathrm{~g}$ lectin $/ \mathrm{kg}$ meal. This value is higher than those previously reported for this legume seed (Allen et al. 1976; Matsumoto et al. 1983).

\section{Animals and diets}

Male rats of the Hooded Lister (Rowett) strain were weaned at $19 \mathrm{~d}$ of age and given a stock diet for $10 \mathrm{~d}$. Rats, matched by weight ( $85 \pm 1 \mathrm{~g}$ in Expt $1,90 \pm 1 \mathrm{~g}$ in Expt 2), were housed singly in metabolism cages based on the design of Schiller (1960), but using glass separators for urine and faeces collection. Food and distilled water were available $a d$ lib. The animals were weighed daily. Urines and faeces were collected daily and stored at $-20^{\circ}$ until required. Faeces samples were freeze-dried and ground in a mortar.

The diets in both expts (Table 1) were formulated to contain the same amount of proteins $(100 \mathrm{~g} / \mathrm{kg})$ and were fully supplemented with amino acids to target requirements (Coates et al. 1969). In addition to the various faba-bean diets, non-protein (NPC) and lactalbumin (LA) control diets were also included. Net protein utilization (NPU), biological value (BV) and true nitrogen, lipid and dry matter (DM) digestibilities (TN dig, TL dig and DM dig respectively) were determined by taking into account the values obtained for the animals fed on the NPC diet. The diet that contained purified VFDP had to be supplemented with lactalbumin to reach $100 \mathrm{~g} / \mathrm{kg}$ final protein concentration. Thus, faba-bean protein accounted for only $65 \mathrm{~g}$ of the total protein in this diet. The diet with VFL was based on lactalbumin and contained three times as much lectin as the faba-bean diets.

Two varieties of faba beans (locally grown, dark seed coats (local VFM) and the cultivar Troy, clear seed coats, from Church (Bures) Ltd (Troy VFM)) were used. In Expt 1, the concentration of VFM was $409 \mathrm{~g} / \mathrm{kg}$ diet; in Expt 2, both meals were tested at a concentration of $439 \mathrm{~g} / \mathrm{kg}$ diet. VFCR from the Troy variety was included in the diet in the 


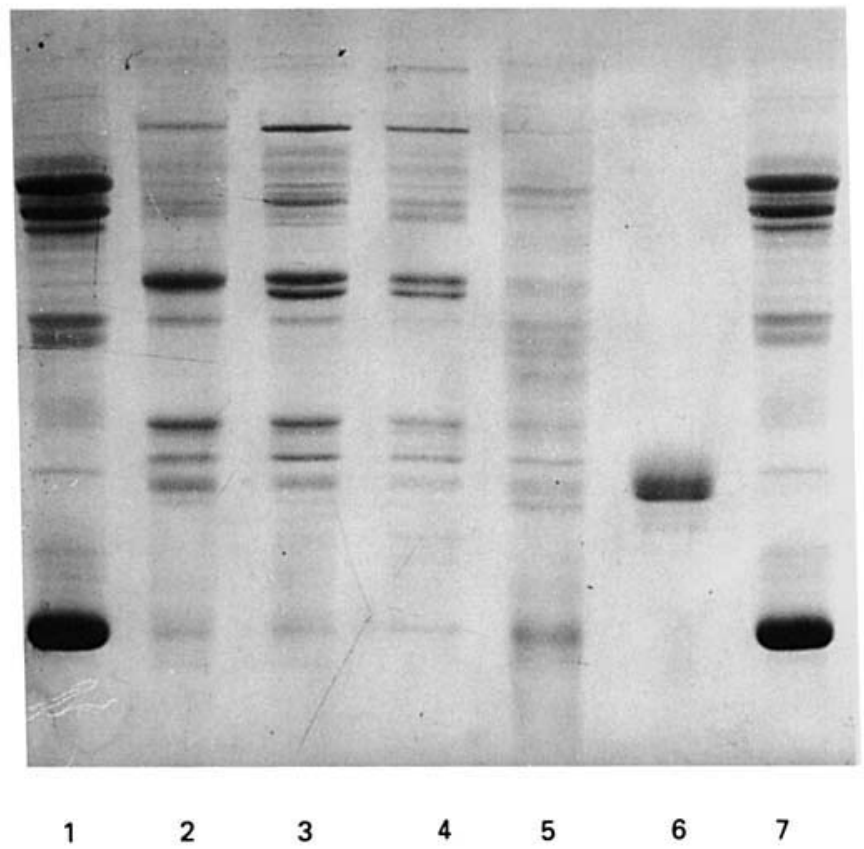

Fig. 1. SDS-PAGE polyacrylamide-gel electrophoresis. 1, marker, Processor bean (Phaseolus vulgaris) 15 $\mathrm{g} / \mathrm{kg}+$ cytochrome $\mathrm{C} I \mathrm{~g} / \mathrm{kg}, 8 \mu \mathrm{l} ; 2$, Vicia faba meal, local cultivar $15 \mathrm{~g} / \mathrm{kg}, 8 \mu \mathrm{l} ; 3$, Vicia faba meal, Troy cultivar $15 \mathrm{~g} / \mathrm{kg}, 8 \mu \mathrm{l} ; 4$, Vicia faba cotyledon insoluble residue, Troy cultivar $15 \mathrm{~g} / \mathrm{kg}, 8 \mu \mathrm{l} ; 5$, Vicia faba lectin-depleted protein, local cultivar $2 \mathrm{~g} / \mathrm{kg}, 12 \mu \mathrm{l} ; 6$, Vicia faba lectin $2 \mathrm{~g} / \mathrm{kg}, 10 \mu 1 ; 7$, marker, Processor bean (P. vulgaris) 15 $\mathrm{g} / \mathrm{kg}+$ cytochrome $\mathrm{C} ! \mathrm{g} / \mathrm{kg}, 6 \mu \mathrm{l}$. The gel was run at constant voltage $(20 \mathrm{~mA})$ for $4 \mathrm{~h}$.

same proportion as that in the seed meal, as calculated from its recovery in the extraction procedure. The energy content of the diets in Expt 2 was increased by the addition of $60 \mathrm{~g}$ maize oil $/ \mathrm{kg}$ (Table 1 ).

\section{Chemical analysis}

Protein. Diets, VFM fractions, faeces, urines and carcasses were analysed for total N (Davidson et al. 1970). Protein content of VFM and fractions (Table 2) was determined as $\mathrm{N} \times 5.4$ (Mosse, 1990). SDS-PAGE (polyacrylamide gel electrophoresis) was carried out following the method of Laemmli (1970).

Lipids. Dietary, faecal and carcass lipids were extracted in chloroform-methanol $(2: 1$, $\mathrm{v} / \mathrm{v}$ ) for $24 \mathrm{~h}$. The difference in the sample weight before and after extraction was taken as the lipid content.

Carbohydrates. The carbohydrate composition of VFCR and whole beans was determined (Table 2). The amounts of free sugars were estimated by high-performance liquid chromatography (HPLC) after extraction with boiling ethanol solution $(800 \mathrm{ml} / \mathrm{l})$, and the starch content was determined by enzyme digestion (Aman \& Hesselman, 1984). Non-starch polysaccharides (NSP) were determined by the Englyst \& Cummings (1984) method. Samples were treated with dimethylsulphoxide to solubilize starch. The starch was hydrolysed with $\alpha$-amylase ( $E C 3.2 .1 .1$ ), pullulanase $(E C 3.2 .1 .41)$ and pancreatin and the NSP precipitated by ethanol $(800 \mathrm{ml} / \mathrm{l})$. Following separation by centrifugation, the NSP were dispersed in $12 \mathrm{M}$-sulphuric acid, diluted to $1 \mathrm{M}$ and hydrolysed. The constituent sugars were determined by gas-liquid chromatography (GLC) as their alditol acetate derivatives. Uronic acids were determined colorimetrically. 
L. A. RUBIO AND OTHERS

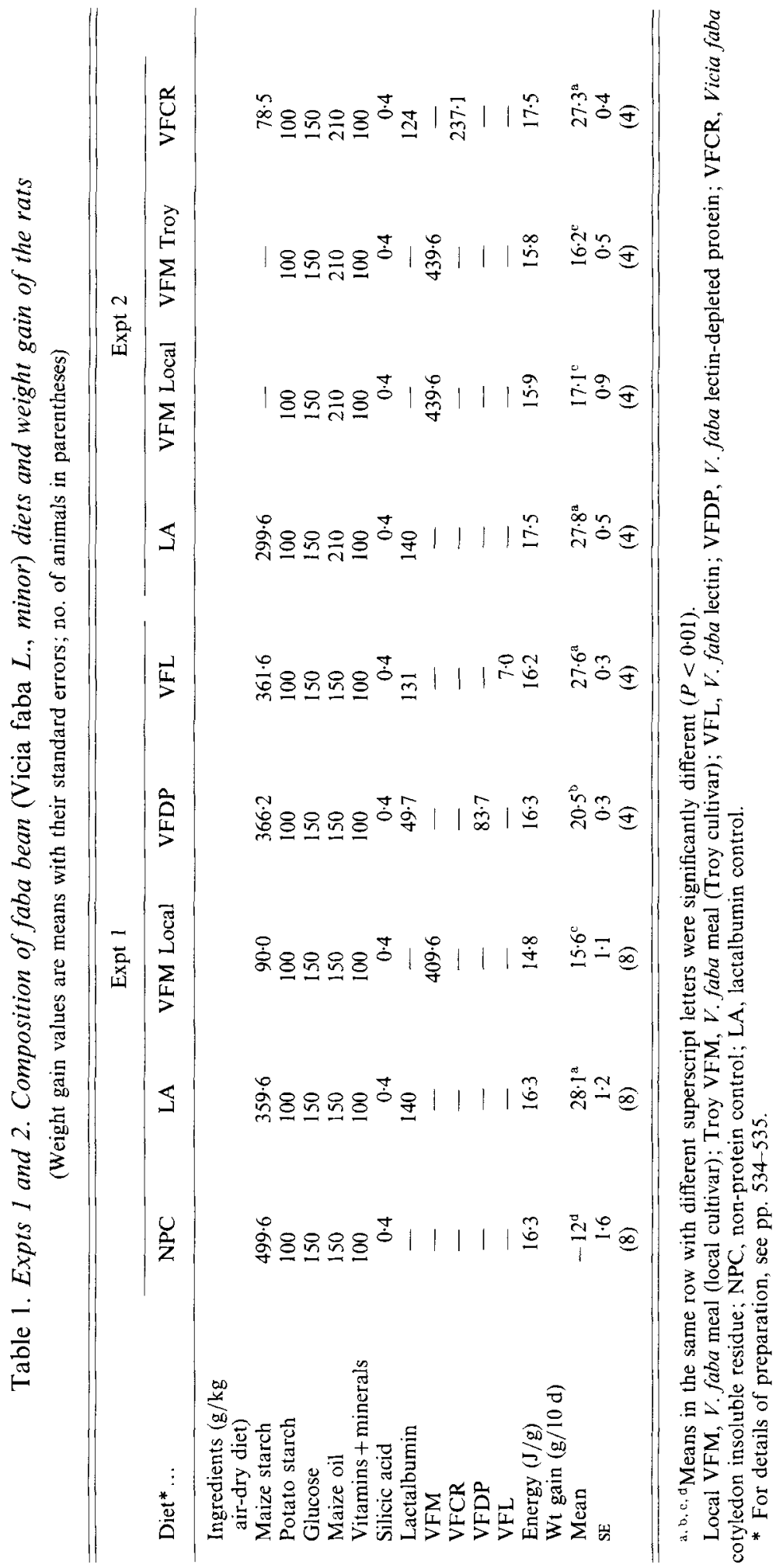


Table 2. Carbohydrate and protein (nitrogen $\times 5 \cdot 4 ;$ Mosse, 1990) composition of Vicia faba meals and fractions* $(\mathrm{g} / \mathrm{kg}$ dry matter)

\begin{tabular}{|c|c|c|c|c|c|}
\hline \multirow[b]{2}{*}{ Variety ... } & \multicolumn{2}{|c|}{ Whole seed } & \multirow[b]{2}{*}{ VFCR Troy } & \multirow[b]{2}{*}{ VFC Troy } & \multirow[b]{2}{*}{ VFDP Local } \\
\hline & Local & Troy & & & \\
\hline Starch & 421 & 1 & 683 & 486 & \\
\hline Total NSP & 166 & & 143 & 106 & \\
\hline Rhamnose & $2 \cdot 2$ & & - & $1 \cdot 0$ & \\
\hline Fucose & 1.6 & & -- & $1 \cdot 0$ & \\
\hline Arabinose & $19 \cdot 6$ & 1 & $33 \cdot 2$ & $23 \cdot 0$ & 1 \\
\hline Xylose & 13.4 & ND & 8.6 & $5 \cdot 5$ & ND \\
\hline Mannose & $1 \cdot 2$ & 1 & - & 0.7 & \\
\hline Galactose & $10 \cdot 8$ & & $24 \cdot 4$ & $18 \cdot 0$ & \\
\hline Glucose & $83 \cdot 0$ & & $40 \cdot 0$ & $27 \cdot 0$ & \\
\hline Uronic acids & $35 \cdot 0$ & & $36 \cdot 5$ & $30 \cdot 0$ & \\
\hline Free sugars & $42 \cdot 0$ & $\mid$ & 1.0 & $51 \cdot 0$ & r \\
\hline Protein & $229 \cdot 7$ & $217 \cdot 7$ & $49 \cdot 0$ & ND & $772 \cdot 0$ \\
\hline
\end{tabular}

VFCR, $V . f a b a$ cotyledon insoluble residue; VFC, $V$. faba cotyledon meal; VFDP, $V$. faba lectin-depleted protein; NSP, non-starch polysaccharides; ND, not determined.

* For details of preparation of fractions, see p. 534 .

In vitro digestion of starch of faba bean was compared with that of commercial (Sigma) untreated maize- and potato-starch samples. In the first step the samples were treated with pepsin-hydrochloric acid at $37^{\circ}$. After neutralization, the samples were quantitatively transferred to small dialysis bags, a solution of pancreatin in phosphate buffer, $\mathrm{pH} 7.5$ was added and the contents were dialysed against this buffer in a shaking water bath. Portions of the diffusate were taken at regular times and analysed for hexose by an anthrone- $\mathrm{H}_{2} \mathrm{SO}_{4}$ procedure (Drake, 1990).

\section{Statistical analysis}

The results were subjected to analysis of variance. Significant differences between means were determined by using Student's $t$ test (Steel \& Torrie, 1960).

\section{RESULTS}

In vitro carbohydrate degradation

In vitro digestion tests with pancreatin (Fig. 2) showed that the carbohydrate digestibility of both VFM and VFC was comparable to that of maize starch.

\section{Purification of lectin}

The lectin was separated from other seed proteins and recovered essentially quantitatively by affinity chromatography on Sephadex G-100. The lectin was shown by SDS gel electrophoresis to be of high purity (Fig. 1).

\section{Growth}

As shown in Table 1, body-weight gain ( $\mathrm{g} / 10 \mathrm{~d}$ per rat) of the animals fed on either whole VFM (local VFM and Troy VFM) or VFDP was significantly lower than that of controls given lactalbumin (LA). Dry body-weights (Tables 3 and 4) were also significantly lower. In contrast, neither the final nor the dry body-weights of VFL- and VFCR-fed animals were significantly different from control values (Tables 3 and 4). 


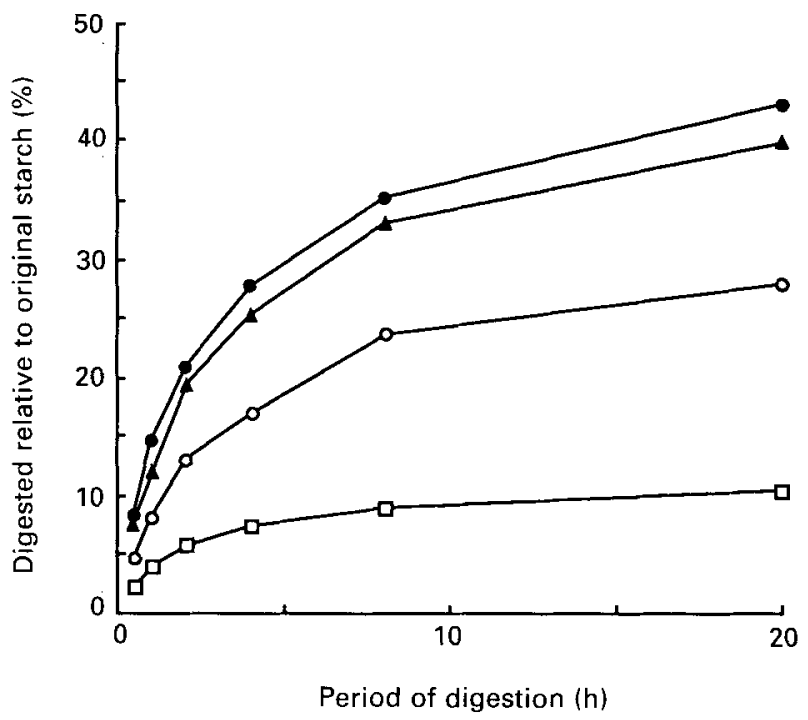

Fig. 2. In vitro digestion of starch carried out with $100 \mathrm{mg}$ of the various materials. Samples of maize and potato starches used as controls were obtained from Sigma (UK) and were tested without pretreatment. (O), Vicia faba meal (Troy cultivar); (A), Vicia faba cotyledon insoluble residue (Troy cultivar);(O), maize starch; ( $\square$ ), potato starch. For details of procedures, see p. 537.

\section{Physiology}

In both experiments, animals fed on VFM excreted significantly higher amounts of faeces (both dry and wet weights; Expt 1), with higher faecal $\mathrm{N}$ and lipid contents, and had lower NPU values and N, DM and lipid digestibilities than the corresponding control (LA) rats. Their urine also contained more $\mathrm{N}$ and urea. In the second experiment, in which local VFM diets of higher energy content were given, the rats excreted more lipid in their faeces. However, these rats had higher dry body-weight, body $\mathrm{N}$ and lipid contents and higher NPU and BV values compared with those fed on local VFM diet with lower maize oil content. Animals given the Troy variety of VFM excreted significantly more faeces of higher lipid content than those fed on the locally grown variety; their body lipid content and true lipid digestibility values were also lower, though not significantly. Feeding rats with diets in which the main protein component was the seed meal from which lectin had been removed (VFDP; Expt 1; Table 3) significantly increased faecal water and $\mathrm{N}$ contents. Moreover, the $\mathrm{N}$ content of their urine was also elevated in comparison with control (LA) animals. Dry body-weight, body N, body lipids, NPU and BV obtained with this diet were significantly lower than control (LA) values. However, faecal excretion of lipids, and true $\mathrm{N}$, lipid and dry matter digestibilities were not significantly affected.

VFL-fed animals excreted significantly higher urea- $N$ in urine than the controls. Consequently, their NPU and BV values were also lower. The nutritional performance of rats given VFCR in the diet (Expt 2) was similar to that of the control animals.

Rats fed on the control (LA) diet in Expt 2 had lower urea $\mathrm{N}$ levels and higher body lipid contents than those in Expt 1.

\section{DISCUSSION}

At the levels of inclusion and under the conditions of these experiments, VFM did not satisfy all the nutritional requirements of growing rats. The low nutritional value of the whole $V$. faba seeds was due primarily to the lower NPU and the lower digestibilities of 
Table 3. Expt 1. Food intake, body and faecal nitrogen and lipid contents, urinary $N$ excretion and digestibilities of $N$ and lipid in rats given diets with Vicia faba meal or its fractions*

(Values are means; no. of animals in parentheses)

\begin{tabular}{|c|c|c|c|c|c|c|}
\hline $\operatorname{Diet}^{\dagger} \ldots$ & $\begin{array}{l}\mathrm{NPC} \\
(8)\end{array}$ & $\begin{array}{l}\text { LA } \\
(8)\end{array}$ & $\begin{array}{l}\text { VFM } \\
(8)\end{array}$ & $\begin{array}{l}\text { VFDP } \\
(4)\end{array}$ & $\begin{array}{l}\text { VFL } \\
(4)\end{array}$ & SED \\
\hline $\begin{array}{l}\text { Food intake }(\mathrm{g} / 10 \mathrm{~d} \\
\text { per rat) }\end{array}$ & $61 \cdot 6^{a}$ & $78 \cdot 3^{\mathrm{b}}$ & $78 \cdot 3^{b}$ & $78 \cdot 3^{i t}$ & $78 \cdot 3^{6}$ & 1.4 \\
\hline \multicolumn{7}{|l|}{ Faecal } \\
\hline Dry wt (g) & $3 \cdot 5^{d}$ & $4 \cdot 3^{\mathrm{a}}$ & $10 \cdot 6^{\mathrm{b}}$ & $5 \cdot 4^{c}$ & $4 \cdot 6^{a}$ & 0.4 \\
\hline Water $(\mathrm{g})$ & $1 \cdot 5^{\mathrm{d}}$ & $2 \cdot 7^{\mathrm{a}}$ & $13 \cdot 5^{\mathrm{b}}$ & $4 \cdot 1^{c}$ & $3 \cdot 5^{\text {ac }}$ & 0.8 \\
\hline$N(\mathrm{mg})$ & $152^{\mathrm{d}}$ & $188^{\mathrm{a}}$ & $386^{b}$ & $233^{\mathrm{c}}$ & $199^{\mathrm{a}}$ & 15 \\
\hline Lipid (mg) & $700^{\mathrm{a}}$ & $636^{a}$ & $1210^{\mathrm{b}}$ & $715^{\mathrm{a}}$ & $650^{\mathrm{a}}$ & 16 \\
\hline Urine $\mathrm{N}(\mathrm{mg})$ & $138^{\mathrm{a}}$ & $142^{\mathrm{a}}$ & $375^{\circ}$ & $308^{\mathrm{c}}$ & $155^{\mathrm{a}}$ & 14 \\
\hline Urea $N(m g)$ & $43^{\mathrm{a}}$ & $52^{\mathrm{a}}$ & $260^{\mathrm{b}}$ & $211^{\circ}$ & $80^{\mathrm{d}}$ & 11 \\
\hline \multicolumn{7}{|l|}{ Body } \\
\hline Dry wt (g) & $24 \cdot 7^{\mathrm{d}}$ & $36 \cdot 3^{\mathrm{a}}$ & $27 \cdot 9^{\mathrm{b}}$ & $30 \cdot 9^{\mathrm{c}}$ & $35 \cdot 7^{\mathrm{a}}$ & $1 \cdot 2$ \\
\hline$N(g)$ & $2 \cdot 27^{\mathrm{c}}$ & $3 \cdot 55^{\mathrm{a}}$ & $2 \cdot 99^{\mathrm{b}}$ & $3 \cdot 21^{\mathrm{b}}$ & $3 \cdot 51^{\mathrm{a}}$ & $0 \cdot 1$ \\
\hline Lipids (g) & $5 \cdot 52^{\mathrm{a}}$ & $6 \cdot 10^{\mathrm{a}}$ & $3 \cdot 68^{b}$ & $4.95^{c}$ & $5.99^{\mathrm{a}}$ & $0 \cdot 3$ \\
\hline Net protein utilization & - & $0 \cdot 97^{\mathrm{a}}$ & $0.55^{\mathrm{b}}$ & $0 \cdot 78^{\circ}$ & $0.92^{\mathrm{d}}$ & 0.03 \\
\hline True $\mathrm{N}$ digestibility & - & $0 \cdot 99^{\mathrm{a}}$ & $0.85^{\mathrm{b}}$ & $0.97^{\mathrm{a}}$ & $0.99^{a}$ & 0.01 \\
\hline Biological value & - & $0.98^{\mathrm{a}}$ & $0.65^{\mathrm{b}}$ & $0 \cdot 80^{\mathrm{bc}}$ & $0.93^{\mathrm{d}}$ & $0 \cdot 03$ \\
\hline True lipid digestibility & - & $0.99^{\mathrm{a}}$ & $0.96^{\mathrm{b}}$ & $0.99^{a}$ & $0.99^{\mathrm{a}}$ & $0-01$ \\
\hline Dry matter digestibility & - & $0 \cdot 99^{\mathrm{a}}$ & $0.91^{\mathrm{b}}$ & $0 \cdot 98^{\mathrm{a}}$ & $0.99^{\mathbf{a}}$ & 0.01 \\
\hline
\end{tabular}

a, b, c, d Means in the same row with different superscript letters were significantly different $(P<0 \cdot 01)$.

* For details of preparation of fractions, see p. 534.

$\dagger$ For details, see Table 1 .

NPC, non-protein control; LA, Jactalbumin control; VFM, Vicia faba meal (local cultivar); VFDP, Vicia faba lectin-depleted proteins; VFL, Vicia faba lectin; SED, standard error of difference.

DM, lipid and $\mathrm{N}$. Thus the BV of the proteins of the meal, even after supplementation to meet all target amino acid requirements, was rather low $(0.65-0.78)$. A similar poor utilization of bean proteins has previously been reported (Abbey et al. 1979; Cenarruzabeitia et al. 1979; Moseley \& Griffiths, 1979). As there has been some dispute as to which factors are responsible for this effect, the main fractions in the seed, namely proteins and carbohydrates, as well as the pure lectin, were examined separately.

Substitution of $65 \mathrm{~g}$ of the $100 \mathrm{~g}$ lactalbumin in the control LA diet with VFDP significantly reduced NPU and BV values of the proteins compared with those of the controls based on lactalbumin entirely. However, VFDP had no effects on true N, lipid and DM digestibilities, indicating that the reduced efficiency of protein utilization was due to increased excretion of $\mathrm{N}$ in the urine (mostly as urea- $\mathrm{N}$ ) leading to lower body $\mathrm{N}$, rather than $\mathrm{N}$ loss through the faeces. Even though this diet was equivalent in energy content to the control (LA) diet, the body lipid content of the animals was lower, suggesting that a higher lipid-energy metabolism may have partly compensated for the less efficient utilization of the protein in VFDP. An increased urinary output of total $\mathrm{N}$ and creatinine in rats fed on whole VFM in the diet has been reported previously (Santidrian et al. 1981).

The low nutritional value of the seed meal was clearly not due to its lectin content, since inclusion of three times as much lectin in the LA diet as found in VFM diets did not influence the growth of the rats (Table 4). This may reflect the fact that VFL, unlike other more deleterious lectins, does not bind to or alter the histological structure of rat enterocytes (Pusztai et al. 1990). This may not be the case for chickens given VFM, which do suffer from intestinal histological disorders (Rubio et al. 1989, 1990). Lectin histochemistry studies (Alroy et al. 1989) have shown that glucose- and mannose-specific 
Table 4. Expt 2. Food intake, body nitrogen and lipid contents, urinary $N$ excretion and digestibilities of $N$ and lipid in rats given diets with Vicia faba meal or its fractions*

(Values are means for four animals)

\begin{tabular}{|c|c|c|c|c|c|c|}
\hline Diet $\uparrow \ldots$ & NPC & LA & $\begin{array}{l}\text { VFM } \\
\text { Local }\end{array}$ & $\begin{array}{l}\text { VFM } \\
\text { Troy }\end{array}$ & VFCR & SED \\
\hline Food intake $(g / 10 \mathrm{~d} / \mathrm{rat})$ & $60 \cdot 2^{\mathrm{a}}$ & $76.5^{b}$ & $76 \cdot 5^{b}$ & $76 \cdot 5^{\mathrm{b}}$ & $76 \cdot 5^{b}$ & 1.4 \\
\hline \multicolumn{7}{|l|}{ Faecal } \\
\hline Dry wt (g) & $3 \cdot 4^{x}$ & $4 \cdot 1^{\mathrm{a}}$ & $12 \cdot 2^{b}$ & $15 \cdot 8^{\mathrm{c}}$ & $5 \cdot 5^{a}$ & 1.5 \\
\hline $\mathrm{N}(\mathrm{mg})$ & $149^{4}$ & $165^{*}$ & $376^{\mathrm{kz}}$ & $393^{\prime \prime}$ & $201^{e}$ & 24 \\
\hline Lipid (mg) & $700^{\mathrm{a}}$ & $703^{a}$ & $1578^{\mathrm{b}}$ & $1960^{\circ}$ & $950^{\mathrm{a}}$ & 83 \\
\hline Urine N (mg) & $135^{\mathrm{a}}$ & $115^{\mathrm{a}}$ & $297^{b}$ & $276^{\mathrm{b}}$ & $128^{\mathrm{a}}$ & 16 \\
\hline Urea $N(\mathrm{mg})$ & $42^{\mathrm{a}}$ & $27^{a}$ & $179^{\mathrm{h}}$ & $148^{\mathrm{b}}$ & $33^{\mathrm{a}}$ & 11 \\
\hline \multicolumn{7}{|l|}{ Body } \\
\hline Dry wt (g) & $26 \cdot 2^{\prime}$ & $36 \cdot 1^{\mathrm{a}}$ & $30 \cdot 9^{b}$ & $30 \cdot 1^{\mathrm{b}}$ & $35 \cdot 5^{\mathrm{a}}$ & $1 \cdot 2$ \\
\hline $\mathrm{N}(\mathrm{g})$ & $2 \cdot 40^{c}$ & $3 \cdot 64^{\mathrm{a}}$ & $3-35^{\mathrm{b}}$ & $3 \cdot 25^{\mathrm{b}}$ & $3.6 \mathrm{I}^{\mathrm{a}}$ & $0 \cdot 11$ \\
\hline Lipid (g) & $5 \cdot 86^{\mathrm{b}}$ & $7 \cdot 29^{\mathrm{a}}$ & $5 \cdot 44^{b}$ & $4.68^{h}$ & $7 \cdot 87^{\mathrm{a}}$ & 0.32 \\
\hline Net protein utilization & - & $0 \cdot 97^{\mathrm{a}}$ & $0 \cdot 66^{\mathrm{b}}$ & $0.62^{\mathrm{b}}$ & $0.94^{4}$ & 0.06 \\
\hline True $\mathrm{N}$ digestibility & - & $0.99^{\mathrm{a}}$ & $0 \cdot 85^{\mathrm{b}}$ & $0.83^{\mathrm{b}}$ & $0 \cdot 96^{\mathrm{a}}$ & 0.06 \\
\hline Biological value & - & $0.98^{\mathrm{a}}$ & $0 \cdot 78^{\mathrm{b}}$ & $0.75^{\prime \prime}$ & $0.98^{\mathrm{a}}$ & 0.08 \\
\hline True ljpid digestibility & - & $0 \cdot 99^{\mathrm{a}}$ & $0.95^{\mathrm{b}}$ & $0.92^{b}$ & $0.99^{: 2}$ & 0.01 \\
\hline Dry matter digestibility & - & $0.99^{\mathrm{a}}$ & $0 \cdot 88^{\mathrm{b}}$ & $0 \cdot 84^{\mathrm{c}}$ & $0.97^{\mathrm{a}}$ & 0.01 \\
\hline
\end{tabular}

a.b.c Means in the same row with different superscript letters were significantly different $(P<0 \cdot 01)$

* For details of preparation, see p. 534.

$\dagger$ For details, see Table 1.

NPC, non-protein control; LA, lactalbumin control; VFM, Vicia faba meal; VFCR, Vicia faba cotyledon insoluble residue; SED, standard error of difference.

lectins (e.g. concanavalin A) bind to the surface of all intestinal segments in the domestic fowl. As VFL has the same specificity, it may bind and be partly responsible for the intestinal disorders and the poor nutritional quality of VFM for chickens. Moreover, this difference in sensitivity to VFL might partly explain the observed less efficient utilization of raw faba beans by chickens compared with rats (Marquardt et al. 1974).

As VFM diets in Expt 1 contained seed coats that are poorly digestible $(<25 \%$, values not shown), the effects of VFM on $\mathrm{N}$ utilization could have been due, at least in part, to a difference in the energy content of the VFM and the control diets. Therefore, in Expt 2 the energy content of the control and test diets was increased, which resulted in increased body $\mathrm{N}$ content of rats fed on either cultivar of beans compared with the values in Expt 1 . However, the NPU values were still lower for the test groups than for control (LA) rats in both experiments. Lipid retention was improved and urinary $\mathrm{N}$ excretion was less in rats fed on the VFM diets with added lipid. Consequently, increased lipid intake led to better growth and higher NPU and BV values. Even the control (LA) animals in Expt 2 retained more lipid and excreted less urea $\mathrm{N}$ than those in Expt 1, suggesting a slightly better protein retention by the body, possibly because of a more favourable energy state of the rats. Despite its lower lipid content, the VFDP-containing diet was similar in energy content to local VFM in Expt 2 (Table 1). Accordingly, the effects of bean proteins on $\mathrm{N}$ utilization should be comparable with the two diets. The reduction in the NPU value from 0.97 (LA diet) to 0.78 (VFDP diet) in Expt 1 must have been due to the substitution by VFDP of $65 \mathrm{~g}$ of the lactalbumin, as this was the only difference between the two diets. Thus, if all the dietary protein had consisted of $V$. faba protein, and the diets were equivalent in energy, the expected difference in NPU between the faba-bean protein and the control (LA) diets would have been $0.29(0 \cdot 19 \times 100 / 65)$. This agrees well with the observed difference of 0.31 in NPU between LA diets generally (0.97) and local VFM in Expt $2(0 \cdot 66)$, supporting the 
conclusion that the protein fraction of VFM is mainly responsible for its low nutritional value. From the different NPU values obtained (i.e. 0.62, 0.66 and 0.69), the average value for $V$. faba meal-containing diets when fed to growing rats in energy-equalized diets was 0.66 (SE 0.02).

There was no difference in true lipid digestibility of the faba-bean diets in the two experiments, as faecal lipid excretion increased in response to increased lipid supply in Expt 2. Despite the fact that the cultivar Troy has much lighter hulls than the local faba bean, the lipid content of the faeces was still high and, therefore, lipid digestibility and body lipid content were low. The hypocholesterolaemic effect is a relatively well-documented aspect of legume consumption (Hellendoorn, 1979), and is generally attributed to the capacity of carbohydrates and other constituents of the fibre fraction to bind bile acids. This would lead to increased bile acid excretion and reduced lipid (and cholesterol) absorption in the intestine (Gallaher \& Schneeman, 1986). Moreover, higher fibre intake might increase not only lipid but also $\mathrm{N}$ excretion (Cummings, 1973). As the faecal excretion of both $\mathrm{N}$ and lipid was significantly higher in VFM-fed rats, but was only marginally increased in animals fed on diets with added bean protein (VFDP) or insoluble carbohydrate (VFCR), the soluble indigestible NSP might play a major role in the antinutritive effects of diets containing whole VFM, as was previously suggested for poultry (Rubio et al. 1990).

As is shown in Table 4, the insoluble carbohydrate fraction remaining after protein extraction (VFCR), which contained most of the starch and the insoluble NSP, was comparable to maize starch in its support of rat growth and in other physiological effects. Moreover, this was supported by the in vitro tests of carbohydrate digestibility, since the results for $V$. faba seeds were comparable to those for maize starch.

In summary, both $\mathrm{N}$ and lipid digestibilities were significantly lower in rats fed on faba bean than in those given control (LA) diet. As $\mathrm{N}$ digestibility was only marginally lower in VFCR- and VFDP-fed animals, this effect, together with the lower lipid digestibility, might be caused by the hull fraction of the seeds or by the unavailability of a part of the diet because of the physicochemical structure of the meal, or both. However, the main reason for the poor $\mathrm{N}$ utilization by the rats fed on isolated $V$. faba protein seems to be the increased excretion of $\mathrm{N}$ in the urine, suggesting disturbances in systemic $\mathrm{N}$ metabolism. The proteins of VFM are not only less nutritious than the control LA but also appear to induce changes in body metabolism, for reasons which are as yet unknown. In contrast, it seems clear that the lectin from this seed has no antinutritional effect on rats, even when included in the diets at levels three times greater than those in the VFM diets. The starch and other insoluble carbohydrates constituting the cotyledon residue are also fully utilized and have no deleterious effect on the growth of rats.

The authors are grateful to $\mathrm{Mr}$ J. C. Stewart for excellent technical assistance. One of us (L.A.R.) is indebted for the financial help and the grants given by the Spanish Ministry of Education and Science (Becas del PFPI) and the British Council. The help of Mr Ian Nevison, Scottish Agricultural Statistics Service, is gratefully acknowledged.

\section{REFERENCES}

Abbey, B. W., Neale, R. J. \& Norton, G. (1979). Nutritional effects of field bean (Vicia faba. L.) proteinase inhibitors fed to rats. British Journal of Nutrition 41, 31-38.

Allen, H. J. \& Johnson, E. A. Z. (1976). Isolation and partial characterization of a lectin from Vicia faba. Biochimica et Biophysica Acta 444, 374-385.

Alroy, J., Goyal, V., Lukacs, N. W., Taylor, R. L., Strout, R. G., Ward, H. D. \& Pereira, M. E. (1989). Glycoconjugates of the intestinal epithelium of the domestic fowl (Gallus domesticus): a lectin histochemistry study. Histochemistry Journal 21, 187-193.

Aman, P. \& Hesselman, K. (1984). Analysis of starch and other main constituents of cereal grains. Swedish Journal of Agricultural Research 14, 135-139. 
Bond, D. A. (1980). Vicia faba: Feeding Value, Processing and Viruses. The Hague: Nijhoff.

Boulter, D. (1982). The composition and nutritional value of legumes by extracts of field bean ( Vicia faba). Journal of the Science of Food and Agriculture 30, 458-462.

Cenarruzabeitia, M. N., Santidrian, S., Bello, J. \& Larralde, J. (1979). Effect of raw field bean (Vicia faba) on amino acid-degrading enzymes in rats and chicks. Nutrition and Metabolism 23, 203-210.

Coates, M. E., O'Donoghue, P. N., Payne, P. R. \& Ward, R. J. (1969). Laboratory Animal Handboaks. 2. Laboratory Standards for Laboratory Rats and Mice, p. 15. London; Laboratory Animals Ltd.

Cummings, J. H. (1973). Progress report: Dietary fibre. Gut 14, 69.

Davidson, J., Mathieson, J. \& Boyne, A. W. (1970). The use of automation in determining nitrogen by the Kjeldahl method, with final calculations by computer. Analyst $95,181-193$.

Drake, A. P. (1990). The development of an in vitro system for predicting nutrient digestibility in feeds for pigs. PhD Thesis, Aberdeen University.

Englyst, H. N. \& Cummings, J. H. (1984). Simplified method for the measurement of total non-starch polysaccharides by gas-liquid chromatography of constituent sugars and alditol acetates. Analyst 109,937-942.

Gallaher, D. \& Schneeman, B. O. (1986). Intestinal interaction of bile acids, phospholipids, dietary fibers, and cholestyramine. American Journal of Physiology 250, 420-426.

Guillaume, J. (1977). Use of field beans (Vicia faba; L.) and peas (Pisum sativum) in laying hen and growing chicken diets. In Protein Quality from Legume Crops, pp. 113-142. Luxembourg: Commission of the European Communities.

Hellendoorn, E. W. (1979). Beneficial physiological activity of leguminous seeds. Quality of Plant Foods for Human Nutrition 29, 227.

Huyghebaert, G., Fontaine, G. \& De Groote, G. (1979). Les féveroles (Vicia faba) en tant que source protéique alternative dans les rations pour poulets de chair. 1. L'effet de divers traitements thermo-mécaniques. (Broad bean (Vicia faba) as an alternative protein source in feed for broiler chicks. 1. The effect of different thermomechanical treatment). Revue de T Agriculture 32, 1243-1255.

Laemmli, U. K. (1970). Cleavage of structural proteins during the assembly of the head of Bacteriophage T4. Nature 227, 680685 .

Marquardt, R. R. \& Campbell, L. D. (1974). Deficiency of methionine in raw and autoclaved faba beans in chicks' diets. Canadian Journal of Animal Science 54, 437-442.

Marquardt, R. R. \& Campbell, L. D. (1975). Performance of chicks fed faba beans (Vicia faba) diets supplemented with methionine, sulphate and cystine. Canadian Journal of Animal Science 55, 213-218.

Marquardt, R. R., Campbell, L. D., Stothers, S. C. \& McKirdy, S. A. (1974). Growth-responses of chicks and rats fed diets containing four cultivars of raw or autoclaved faba beans. Canadian Journal of Animal Science 54, $177-182$.

Martinez, J. A. \& Larralde, J. (1984). Influence of diets containing different levels of Vicia faba L. as source of protein on body composition and nitrogen balance for growing rats. Annals of Nutrition and Metabolism 28, 174-180.

Matsumoto, L., Vehara, Y., Jimbo, A. \& Seno, N. (1983). Immunochemical and spectral studies on Vicia faba agglutinin. Journal of Biochemistry, Tokyo 93, 763-769.

Mercier, C. (1979). Les a-galactosides des graines de legumineuses. (The $\alpha$-galactosides of legume seeds.) In Matières Premières et Alimentation des Volailles, pp. 79-90. Versailles: Institut National de la Recherche Agronomique.

Moseley, G. \& Griffiths, D. W. (1979). Varietal variation in the antinutritive effects of field beans (Vicia faba) when fed to rats. Journal of the Science of Food and Agriculture 30, 772-778.

Mosse, J. (1990). Nitrogen to protein conversion factor for ten cereals and six legumes or oilseeds. A reappraisal of its definition and determination. Variation according to species and to seed protein content. Journal of Agricultural and Food Chemistry 38, 18-24.

Pusztai, A., Ewen, S. W. B., Grant, G., Peumans, W. J., Van Damme, E. J. M., Rubio, L. \& Bardocz, S. (1990). Relationship between survival and binding of plant lectins during small intestinal passage and their effectiveness as growth factors. Digestion 46, Suppl. 2, 308-316.

Rubio, L. A. \& Brenes, A. (1988). Plasma mineral concentrations in growing chickens fed diets containing raw and autoclaved faba beans (Vicia faba L.) and faba bean fractions. Nutrition Reports International 38, 609-619.

Rubio, L. A., Brenes, A. \& Castano, M. (1989). Histological alterations of the pancreas and the intestinal tract produced by raw faba bean (Vicia faba L., minor) diets in growing chicks. British Poultry Science 30, 15-28.

Rubio, L. A., Brenes, A. \& Castano, M. (1990). The utilization of raw and autoclaved faba beans (Vicia faba L., minor) and faba bean fractions in diets for growing broiler chickens. British Journal of Nutrition 63, 419-433.

Santidrian, S., Sobrini, F. J., Bello, J. \& Larralde, J. (1981). Guanidinoacetate methyltransferase activity in growing male rats fed on a raw field bean (Vicia faba L.) diet. Enzyme 26, 103-106.

Schiller, K. (1960). Ein Stoffwechselkäfg für Ratten. (A metabolism cage for rats.) Zeitschrift für Tierphysiologie, Tierernährung und Futtermittelkunde 15, 305-308.

Steel, R. G. D. \& Torrie, J. H. (1960). Principles and Procedures of Statistics. New York: McGraw-Hill 